\title{
Pengaruh Rasio Likuiditas, Rasio Solvabilitas, dan Rasio Aktivitas terhadap Kinerja Keuangan Perusahaan
}

\author{
Anneke Maria Indriastuti dan Herman Ruslim \\ Program Studi Manajemen Fakultas Ekonomi \& Bisnis \\ Universitas Tarumanagara \\ Email: anneke.115160340@stu.untar.ac.id
}

\begin{abstract}
This study aims to find out the effect of liquidity ratio, solvency ratio, and activity ratio against the company's financial performance simultaneously or partially. The independent variable in this study is the Current Ratio, Debt to Equity Ratio, and Total Asset Turnover, while the dependent variable is the Return On Equity. The study is conducted at the companies in Health and Pharmaceutical sectors listed in Indonesia Stock Exchange in the period of 2014-2018. This study adopted the panel data regression method using Eviews 11 as its tool. Result of research indicates that Current Ratio, Debt to Equity Ratio and Total Asset Turnover are influential simultaneously and significantly to Return On Equity. Debt to Equity Ratio is influential partially and significantly to Return On Equity. However, Current Ratio and Total Asset Turnover are not influential significantly to Return On Equity.
\end{abstract}

Keywords: likuidity ratio, solvency ratio, activity ratio, financial performance.

\begin{abstract}
Abstrak: Tujuan dari penelitian ini adalah untuk mengetahui besarnya pengaruh rasio likuiditas, rasio solvabilitas, dan rasio aktivitas terhadap kinerja keuangan perusahaan baik secara simultan maupun parsial. Variabel bebas dalam penelitian ini adalah Current Ratio (CR), Debt to Equity Ratio (DER), dan Total Asset Turnover (TATO), sedangkan variabel terikatnya adalah Return On Equity (ROE). Penelitian dilakukan pada perusahaan sektor kesehatan dan farmasi yang terdaftar di Bursa Efek Indonesia periode 2014-2018. Penelitian ini menggunakan regresi data panel dengan aplikasi Eviews 11. Hasil penelitian menyimpulkan bahwa terdapat pengaruh secara simultan dari variabel Current Ratio, Debt to Equity Ratio, dan Total Asset Turnover terhadap Return On Equity. Secara parsial hasil menunjukkan bahwa hanya variable Debt to Equity Ratio yang memiliki pengaruh signifikan terhadap Return On Equity, sedangkan Current Ratio dan Total Asset Turnover tidak berpengaruh secara signifikan terhadap Return On Equity.
\end{abstract}

Kata kunci: rasio likuiditas, rasio solvabilitas, rasio aktivitas, kinerja keuangan.

\section{LATAR BELAKANG}

Industri Farmasi Indonesia merupakan salah satu terbaik di ASEAN, hal ini dikemukakan oleh Sie Djohan selaku Direktur Business Development PT Kalbe Farma. Indonesia memiliki beberapa faktor yang dapat mendorong perusahaan Kesehatan dan Farmasi untuk terus bertumbuh sehingga Indonesia dapat menjadi tempat usaha yang menjanjikan dengan adanya peningkatan jumlah penduduk di Indonesia yang besar, tingkat kesadaran masyarakat pun akan kesehatan serta obat-obatan semakin tinggi, tingkat perekonomian masyarakat semakin meningkat dan akses kesehatan yang meningkat seiring berjalannya waktu dengan implementasi BPJS Kesehatan.

Dengan kondisi perekonomian yang semakin rumit dan tidak menentu, banyak perusahaan yang tiba-tiba mengalami kebangkrutan yang dikarenakan perusahaan tidak dapat mencermati kondisi keuangan dan kinerjanya. Oleh karena itu setiap perusahaan dituntut 
untuk bisa meningkatkan kinerja perusahaan yang lebih baik. Kondisi kinerja perusahaan dapat dilihat melalui laporan keuangan dari setiap perusahaan. Laporan keuangan tersebut akan dapat memperlihatkan seperti apa posisi keuangan perusahaan mulai dari harta, utang, modal serta hasil yang dihasilkan dari setiap kegiatan yang ada dalam perusahaan. Rasio keuangan merupakan alat analisis dalam menganalisa dan menilai kondisi serta posisi keuangan suatu perusahaan. Rasio keuangan dapat memberikan gambaran kondisi perusahaan. Maka dari itu laporan keuangan perlu untuk dianalisa agar dapat mengetahui posisi dan kondisi kinerja perusahaan.

Dalam mengukur keberhasilan perusahaan dapat digunakan beberapa rasio yaitu rasio solvabilitas, rasio profitabilitas, dan rasio aktivitas. Rasio solvabilitas merupakan kemampuan suatu perusahaan dalam memenuhi kewajiban keuangan (kewajiban keuangan jangka pendek ataupun jangka panjang) jika perusahaan tersebut dalam masa likuidasi (Munawir, 2007). Adapun rasio profitabilitas menunjukan kemampuan perusahaan dalam menghasilkan keuntungan. Sedangkan rasio aktivitas bagaimana sumber daya telah dimanfaatkan secara optimal, kemudian dengan cara membandingkan rasio aktivitas, maka dapat diketahui tingkat efesiensi perusahaan dalam industri (Agus Sartono, 2012a, h. 118).

Dari beberapa rasio keuangan yang ada, tiga rasio tersebut sering digunakan oleh para peneliti dalam meneliti kinerja keuangan perusahaan. Rasio likuiditas sering diasosiasikan dengan Current Ratio (CR). Current Ratio (CR) adalah ukuran yang umum digunakan atas solvensi jangka pendek, kemampuan suatu perusahaan memenuhi kebutuhan utang ketika jatuh tempo. Current Ratio menunjukkan sejauh mana aktiva lancar menutupi kewajibankewajiban lancar. Current Ratio digunakan untuk mengukur kemampuan korporasi dalam memenuhi kewajiban jangka pendek, dengan asumsi bahwa semua aktiva lancar dikonversikan ke dalam kas. Selanjutnya rasio solvabilitas sering diasosiasikan dengan Debt to Equity Ratio (DER). Debt to Equity Ratio (DER) adalah rasio yang digunakan untuk mengukur hutang dalam ekuitas. Rasio ini dihitung dengan cara membandingkan semua utang, termasuk utang jangka pendek dengan total aset bersih yang dimiliki oleh perusahaan (Kasmir, 2013). Lalu rasio aktivitas sering diasosiasikan dengan Total Asset Turnover (TATO). Total Asset Turnover adalah ukuran keseluruhan dari perputaran aset. Rasio ini cukup sering digunakan sebagai ruang lingkup yang komprehensif. Terlepas dari jenis bisnisnya, rasio ini dapat menggambarkan seberapa baik dukungan semua aset untuk mendapatkan penjualan (Prihadi, 2008). Dan yang terakhir, rasio profitabilitas sering diasosiasikan dengan Return On Equity (ROE). Tingkat Return On Equity memiliki hubungan positif dengan harga saham, jadi semakin besar Return On Equity maka semakin besar pula harga pasar. Karena jumlah Return On Equity memberikan indikasi pengembalian yang akan diterima oleh investor tinggi sehingga investor akan tertarik membeli saham, dan ini menyebabkan harga pasar saham cenderung naik.

Alasan menggunakan obyek penelitian di sektor Kesehatan dan Farmasi yaitu, sektor Kesehatan dan Farmasi akan survive dibandingkan dengan sektor lainnya, sebab dalam kondisi krisis ataupun tidak, sektor Kesehatan dan Farmasi tetap dibutuhkan.

Oleh karena itu, dari pemaparan di atas inilah yang mendasari ketertarikan peneliti untuk mengangkat ke dalam penelitian yang berjudul "Pengaruh Rasio Likuiditas, Rasio Solvabilitas, Dan Rasio Aktivitas Terhadap Kinerja Keuangan Perusahaan Kesehatan Dan Farmasi Yang Terdaftar Di Bursa Efek Indonesia Tahun 2014-2018”.

\section{KAJIAN TEORI}

Laporan Keuangan. Laporan keuangan adalah gambaran perusahaan pada waktu tertentu, yang menunjukkan kondisi keuangan perusahaan yang telah dicapai dalam jangka waktu tertentu. Laporan keuangan adalah sarana utama yang digunakan untuk tujuan pengumpulan, 
pemrosesan dan penyajian informasi ekonomi. Tujuan dari laporan keuangan adalah untuk memberikan informasi tentang posisi dan perubahan keuangan sebagai dasar yang sangat penting untuk membuat keputusan manajerial (Asllanaj, 2008). Tujuan dari laporan keuangan adalah untuk memberikan informasi tentang situasi keuangan, kinerja keuangan dan perubahan posisi keuangan entitas yang dapat digunakan oleh berbagai pengguna dalam membuat keputusan ekonomi mereka (Lewis \& Pendrill, 2004).

Analisis Laporan Keuangan. Manfaat analisis rasio tidak hanya berguna untuk keperluan internal perusahaan tetapi juga untuk orang luar yang merupakan investor potensial yang ingin berinvestasi di perusahaan melalui pasar modal. Untuk manajer perusahaan, dengan menganalisis rasio keuangan akan mendapatkan informasi tentang kekuatan dan kelemahan yang dihadapi oleh perusahaan di sektor keuangan, sehingga membuat keputusan penting bagi perusahaan di masa depan. Adapun calon investor, laporan keuangan adalah pertimbangan material apakah menguntungkan untuk membeli saham perusahaan yang bersangkutan atau tidak. Analisis laporan keuangan memerlukan interpretasi yang bertujuan memantau kinerja keuangan perusahaan. Untuk mencapai itu, laporan keuangan digunakan sebagai sumber untuk menghitung indikator. Dengan demikian, ukuran kinerja keuangan adalah dianggap alat manajemen yang sangat penting (Gitman, 2010).

Rasio Keuangan. Jenis rasio keuangan yang dapat digunakan untuk menilai kinerja manajemen sangat beragam. Rasio keuangan telah sering digunakan untuk mengevaluasi kinerja perusahaan oleh berbagai jenis profesional. Andrew dan Schmidgall (1993) menyatakan bahwa rasio keuangan mengandung informasi yang lebih berharga bagi investor, kreditor dan manajer daripada angka absolut yang ditemukan dalam laporan keuangan. Menurut Sartono (2008, h. 114) Rasio keuangan dikelompokkan menjadi empat kelompok, yaitu:

\section{Rasio Likuiditas}

Rasio likuiditas diwakili oleh Current Ratio (CR). Current Ratio menunjukkan untuk pembayaran kembali current liabilities dijamin oleh current asset. Semakin tinggi rasio aktiva lancar terhadap kewajiban lancar, maka semakin tinggi kemampuan perusahaan untuk menutupi kewajiban jangka pendeknya (Hidayat, 2010, h. 120).

2. Rasio Solvabilitas

Rasio Solvabilitas diwakili oleh Debt to Equity Ratio (DER). Debt to Equity Ratio adalah rasio yang digunakan untuk menilai hutang dengan ekuitas (Kasmir, 2015). Rasio ini menunjukkan komposisi atau struktur dari total modal pinjaman (hutang) terhadap total modal (ekuitas) perusahaan dalam memenuhi kewajiban jangka panjangnya. Semakin besar penggunaan hutang dibandingkan dengan modal sendiri menyebabkan penurunan nilai perusahaan, ini juga merupakan pertimbangan yang sangat penting bagi investor dalam nilai perusahaan.

\section{Rasio Aktivitas}

Rasio aktivitas diwakili oleh Total Asset Turnover. Total Asset Turnover adalah rasio keuangan yang digunakan untuk mengukur pergantian semua aset yang dimiliki perusahaan dan mengukur berapa banyak penjualan yang diperoleh dari setiap rupiah aset (Kasmir, 2015). Semakin tinggi rasio Total Asset Turnover berarti semakin efisien penggunaan semua aset dalam menghasilkan penjualan, 
jumlah aset yang sama dapat meningkatkan volume penjualan jika Total Asset Turnover meningkat atau diperbesar.

\section{Rasio Profitabilitas}

Rasio profitabilitas diwakili oleh Return On Equity (ROE). Return On Equity adalah analisis yang biasa digunakan oleh investor dan pemimin perusahaan, untuk mengukur berapa banyak laba yang bisa menjadi modal pemilik sendiri. Return On Equity adalah ukuran pendapatan (income) yang tersedia untuk pemilik perusahaan (baik pemegang saham biasa maupun pemegang saham preferen) atas modal yang mereka investasikan di perusahaan. Secara umum, semakin tinggi pengembalian atau pendapatan yang diperoleh, semakin baik posisi pemilik perusahaan (Lukman Shamsuddin, 2002, h. 64).

Kinerja Keuangan Perusahaan. Untuk memutuskan suatu badan usaha atau perusahaan memiliki kualitas yang baik maka ada penilaian yang paling dominan yang dapat dijadikan acuan untuk melihat badan usaha atau perusahaan tersebut telah menjalankan suatu kaidahkaidah manajemen yang baik. Kinerja keuangan perusahaan dibagi menjadi dua kategori umum: yang pertama berkaitan dengan pengembalian ke investor; yang kedua merujuk pengembalian akuntansi (laba) (Cochran \& Wood, 1984). Ada beberapa kelompok ukuran kinerja keuangan yang dapat digunakan oleh perusahaan dan salah satunya adalah menggunakan rasio profitabilitas. Rasio ini dirasa tepat karena dapat mengukur bagaimana kinerja perusahaan dilihat dari penggunaan aktiva dan modal yang ada. Sebab aktiva dan modal merupakan komponen penting dalam proses kegiatan oprasional perusahaan.

\section{Pengaruh Current Ratio, Debt to Equity Ratio dan Total Asset Turnover Terhadap Return On Equity}

Current Ratio (CR) digunakan untuk membandingkan aktiva lancar dengan utang lancar yang harus dibayarkan perusahaan. Perubahan Current Ratio dipengaruhi oleh perubahan pada aktiva lancar atau utang lancar maupun keduanya, yang juga mengakibatkan tingkat likuiditas berubah. Dampak dari nilai likuiditas yang tinggi menyebabkan adanya kelebihan modal kerja yang dibutuhkan, kelebihan ini akan menurunkan kesempatan perusahaan untuk memperoleh keuntungan, sehingga berdampak kurang baik terhadap earning power. Dengan demikian sangat dimungkinkan hubungan Current Ratio dengan Return On Equity adalah negatif. Semakin tinggi nilai Current Ratio menyebabkan semakin rendahnya tingkat Return On Equity. Begitupun sebaliknya, nilai Current Ratio yang rendah menyebabkan semakin tingginya tingkat Return On Equity.

Perbandingan antara total utang perusahaan dengan total modal sendiri dinyatakan dalam Debt to Equity Ratio (DER). Nilai Debt to Equtiy Ratio yang tinggi menyebabkan tingkat utang semakin tinggi. Tingkat utang yang tinggi akan mengurangi keuntungan sehingga mempunyai dampak buruk terhadap kinerja perusahaan. Sebaliknya, tingkat Debt to Equity Ratio yang rendah menyebabkan tingkat pengembalian yang semakin tinggi, sehingga menunjukkan kinerja perusahaan yang semakin baik. Tinggi rendahnya nilai Debt to Equity Ratio akan mempengaruhi tingkat Return On Equity yang dicapai oleh perusahaan. Sumber dana yang berasal dari pinjaman atau utang akan lebih efektif dalam menghasilkan laba (meningkatkan Return On Equity) jika biaya yang ditimbulkan oleh pinjaman (cost of debt) lebih kecil dari pada biaya modal sendiri (cost of equity), demikian pula sebaliknya.

Total Asset Turnover (TATO) merupakan rasio perbandingan antara penjualan yang dihasilkan dengan total aktiva yang dimiliki perusahaan. Total Asset Turnover dipengaruhi oleh besar kecilnya penjualan dan total aktiva, baik aktiva lancar maupun aktiva tetap. Semakin tinggi Total Asset Turnover suatu perusahaan, maka perusahaan akan semakin 
efektif dalam mengelola asetnya dan semakin baik pula tingkat efisiensi dalam penggunaan aktiva untuk menunjang penjualan. Semakin tinggi nilai Total Asset Turnover menyebabkan semakin tingginya tingkat Return On Equity karena dengan meningkatnya perputaran aset akan dapat meningkatkan volume penjualan untuk mendapatkan laba yang maksimal, sehingga semakin cepat tingkat perputaran aktiva maka semakin cepat peningkatan laba yang dihasilkan oleh perusahaan, begitupun sebaliknya.

Berdasarkan landasan teori yang sudah dipaparkan di atas, model kerangka berpikir menggambarkan variabel bebas yang terdiri dari Current Ratio $\left(\mathrm{X}_{1}\right)$, Debt to Equity Ratio $\left(\mathrm{X}_{2}\right)$, Total Asset Turnover $\left(\mathrm{X}_{3}\right)$ yang akan mempengaruhi variabel terikat yaitu Return On Equity (Y) baik secara simultan maupun parsial.

H1 : Current Ratio berpengaruh positif terhadap Return On Equity perusahaan kesehatan dan farmasi.

H2 : Debt to Equity Ratio berpengaruh positif terhadap Return On Equity perusahaan kesehatan dan farmasi.

H3 : Total Asset Turnover berpengaruh positif terhadap Return On Equity perusahaan kesehatan dan farmasi.

H4 : Current Ratio, Debt to Equity Ratio, dan Total Asset Turnover secara bersamasama berpengaruh signifikan terhadap Return On Equity perusahaan kesehatan

\section{METODOLOGI} dan farmasi.

Desain penelitian adalah prosedur untuk mengumpulkan, menganalisis, menafsirkan, dan melaporkan data dalam studi penelitian (Creswell \& Plano Clark 2007, h. 58). Dalam penelitian ini sampel diambil dengan menggunakan teknik purposive sampling. Teknik purposive samping adalah proses dari memilih sampel dengan mengambil subjek yang tidak didasarkan pada level atau area, tetapi diambil berdasarkan tujuan tertentu (Arikunto, 2010, h. 183).

Sampel diteliti menggunakan data dari tahun 2014 sampai tahun 2018. Data kuantitatif diambil dari situs web Bursa Efek Indonesia (BEI), yaitu laporan keuangan Perusahaan kesehatan dan farmasi yang akan diobservasi. Data yang digunakan adalah data sekunder.

\section{HASIL UJI STATISTIK}

Tabel 1. Fixed Effect Model

\begin{tabular}{crlrl}
\hline \multicolumn{1}{c}{ Variable } & Coefficient & \multicolumn{1}{c}{ Std. Error } & t-Statistic & \multicolumn{1}{c}{ Prob. } \\
\hline C & 0.479364 & 9.889217 & 0.048473 & 0.9616 \\
X1 & -0.004652 & 0.024844 & -0.187265 & 0.8523 \\
X3 & -1.563387 & 0.503995 & -3.101989 & 0.0033 \\
& 17.50050 & 9.076313 & 1.928151 & 0.0602 \\
\hline \multicolumn{5}{c}{ Effects Specification } \\
\hline Cross-section fixed (dumın variables) & & \\
\hline Root MSE & 14.22144 & R-squared & 0.705814 \\
Mean dependent var & 15.68124 & Adjusted R-squared & 0.614289 \\
S.D. dependent var & 26.44125 & S.E. of regression & 16.42150 \\
Akaike info criterion & 8.647378 & Sum squared resid & 12134.95 \\
Schwarz criterion & 9.170964 & Log likelihood & 244.4213 \\
Hannan-Quinn criter. & 8.852181 & F-statistic & 7.711745 \\
Durbin-Watson stat & 1.507377 & Prob(F-statistic) & 0.000000 \\
\hline
\end{tabular}


Sumber: data diolah

Hasil pemilihan Uji Chow dan Uji Hausman menunjukkan Chi-Square dan cross-section random sebesar 0,0000, yaitu lebih kecil dari 0,05 yang mengartikan bahwa $\mathrm{H}_{0}$ ditolak, dan model yang tepat untuk digunakan adalah Fixed Effect Model.

Current Ratio berpengaruh secara negatif dan tidak signifikan terhadap Return On Equity perusahaan Kesehatan dan Farmasi tahun 2014-2018. Dalam penelitian ini, diketahui bahwa nilai probabilitas sebesar 0,8523 yang dapat dinyatakan bahwa probabilitas lebih besar dari nilai tingkat keyakinan sebesar 0,05 , sehingga dapat diartikan tidak memiliki pengaruh yang signifikan.

Debt to Equity Ratio berpengaruh secara negatif dan signifikan terhadap Return On Equity perusahaan Kesehatan dan Farmasi tahun 2014-2018. Dalam penelitian ini, diketahui bahwa nilai probabilitas sebesar 0,0033 yang dapat dinyatakan bahwa probabilitas lebih kecil dari nilai tingkat keyakinan sebesar 0,05 , sehingga dapat diartikan memiliki pengaruh yang signifikan.

Total Asset Turnover memiliki nilai yang positif dan tidak signifikan terhadap Return On Equity perusahan Kesehatan dan Farmasi tahun 2014-2018. Dalam penelitian ini, diketahui bahwa nilai probabilitas sebesar 0,0602 yang dapat dinyatakan bahwa probabilitas lebih besar dari nilai tingkat keyakinan sebesar 0,05 , sehingga dapat diartikan tidak memiliki pengaruh yang signifikan.

Current Ratio, Debt to Equity Ratio, dan Total Asset Turnover secara bersama sama berpengaruh signifikan terhadap ROE (Return On Equity) perusahaan Kesehatan dan Farmasi tahun 2014-2018. Dalam penelitian ini, diketahui bahwa nilai probabilitas sebesar 0,0000 dimana nilai tersebut lebih kecil dari nilai tingkat keyakinan sebesar 0,05 , sehingga dapat diartikan memiliki pengaruh yang signifikan.

\section{DISKUSI}

Pengaruh Current Ratio (CR) Terhadap Return On Equity (ROE). Current Ratio berpengaruh negatif dan tidak signifikan terhadap Return On Equity perusahaan Kesehatan dan Farmasi. Sangat dimungkinkan hubungan Current Ratio dengan Return On Equity negatif, karena semakin tinggi nilai Current Ratio menyebabkan semakin rendahnya tingkat Return On Equity. Namun di sisi lain, semakin tinggi nilai Current Ratio maka akan berdampak pada penurunan nilai return saham. Variabel pengaruh Current Ratio menunjukkan hasil tidak signifikan terhadap Return On Equity karena investor kurang menganggap penting akan laba bersih dan tingkat penjualan yang dilakukan perusahaan. Sesuai dengan teori sinyal (Signaling Theory), pada penelitian ini kondisi tersebut mengurangi minat para investor untuk berinvestasi karena para investor melihat bahwa perusahaan tersebut tidak dapat menggunakan kas dengan sebaik mungkin sehingga dapat dikategorikan sebagai sinyal buruk (bad news) karena mengindikasikan kondisi perusahaan yang tidak baik. Hasil dari penelitian ini sesuai dengan penelitian oleh Pongrangga, Dzulkirom, dan Saifi (2015) yang menyatakan bahwa Current Ratio (CR) tidak berpengaruh signifikan terhadap Return On Equity (ROE).

Pengaruh Debt to Equity Ratio (DER) Terhadap Return On Equity (ROE). Debt to Equity Ratio berpengaruh negatif dan signifikan terhadap Return On Equity perusahaan Kesehatan dan Farmasi. Dari uraian penjelasan tersebut dapat dijelaskan bahwa jika terjadi adanya kenaikan maupun penurunan yang terjadi pada Debt to Equity Ratio maka akan memiliki dampak terhadap kenaikan maupun penurunan yang terjadi terhadap Return On Equity. Return perusahaan dipengaruhi oleh Debt to Equity Ratio perusahaan. Yang berarti semakin besar tingkat Debt to Equity Ratio perusahaan, maka kinerja keuangan perusahaan semakin 
baik. Hasil penelitian ini mendukung penelitian Hantono (2015) yang menyatakan bahwa Debt to Equity Ratio (DER) berpengaruh negatif dan signifikan terhadap Return On Equity (ROE).

Pengaruh Total Asset Turnover (TATO) Terhadap Return On Equity (ROE). Total Asset Turnover berpengaruh positif dan tidak signifikan terhadap Return On Equity perusahaan Kesehatan dan Farmasi. Oleh karena itu hal ini dapat diartikan bahwa Total Asset Turnover tidak dapat digunakan sebagai dasar dalam menentukan besar kecilnya laba perusahaan Kesehatan dan Farmasi. Sesuai dengan teori sinyal (Signaling Theory) yang menyatakan bahwa pengambilan keputusan para investor dipengaruhi oleh rasio pada laporan keuangan. Berdasarkan teori sinyal, pada penelitian ini kondisi tersebut dapat dikategorikan menjadi sinyal buruk (bad news) karena kemampuan Total Asset Turnover dalam menciptakan penjualan tidak dapat meningkatkan laba perusahaan perusahaan sehingga menggambarkan kondisi perusahaan yang tidak baik. Hasil dari penelitian ini sesuai dengan penelitian yang dilakukan oleh Destari dan Hendratno (2019) yang menyatakan bahwa secara parsial Total Asset Turnover (TATO) tidak memiliki pengaruh signifikan terhadap Return On Equity (ROE).

Pengaruh Current Ratio, Debt to Equity Ratio, dan Total Asset Turnover Terhadap Return On Equity. Current Ratio, Debt to Equity Ratio, dan Total Asset Turnover secara bersama-sama berpengaruh positif dan signifikan terhadap perusahaan Kesehatan dan Farmasi. Dapat disimpulkan bahwa ketiga variabel dapat berpengaruh secara positif terhadap Return On Equity sehingga jika ketiga variabel secara bersama-sama mengalami kenaikan maupun penurunan maka akan memiliki pengaruh dan mengakibatkan kenaikan maupun penurunan yang sama terhadap Return On Equity. Dengan kenaikan tiap variabel akan mempengaruhi kenaikan terhadap variabel dependen Return On Equity. Hasil penelitian ini sesuai dengan penelitian yang dilakukan oleh Aminatuzzahra (2010) yang menyatakan bahwa variabel Current Ratio, Debt to Equity Ratio, dan Total Asset Turnover secara simultan berpengaruh signifikan terhadap variabel Return On Equity (ROE).

\section{KESIMPULAN}

Setelah dilakukan pengujian, maka diperoleh kesimpulan dari penelitian ini sebagai berikut:

1. Current Ratio berpengaruh secara negatif dan tidak signifikan terhadap Return On Equity perusahaan Kesehatan dan Farmasi.

2. Debt to Equity Ratio berpengaruh negatif dan signifikan terhadap Return On Equity perusahaan Kesehatan dan Farmasi.

3. Total Asset Turnover berpengaruh positif dan tidak signifikan terhadap Return On Equity perusahaan Kesehatan dan Farmasi.

4. Current Ratio, Debt to Equity Ratio, dan Total Asset Turnover secara bersama-sama berpengaruh positif dan signifikan terhadap perusahaan Kesehatan dan Farmasi.

Penelitian ini tentu nya memiliki beberapa keterbatasan, diantaranya yaitu jumlah sampel yang diteliti dalam penelitian ini hanya terdiri dari 12 perusahaan Kesehatan dan Farmasi. Rentang periode yang diambil hanya 5 tahun, yaitu dari tahun 2014 sampai 2018. Maka dari itu beberapa saran yang dapat diberikan adalah perusahaan Kesehatan dan Farmasi dapat meningkatkan nilai Return on Equity karena nilainya yang dominan, serta meningkatkan Debt to Equity Ratio diikuti Current Ratio untuk meningkatkan return saham, agar saham semakin diminati. Penelitian selanjutnya disarankan menggunakan jumlah sampel 
yang lebih banyak dan tidak menggunakan data tahunan kembali agar penelitian lebih spesifik.

\section{DAFTAR PUSTAKA}

Agus Sartono. (2008). Manajemen Keuangan. Teori dan Aplikasi. Edisi Empat. Yogyakarta: BPFE.

Arikunto, Suharsimi. (2010). Prosedur Penelitian. Suatu Pendekatan Praktik. Jakarta: Rineka Cipta.

Chad J Zutter. (2012). Principles of Managerial Finance. Thirteenth Edition. Essex: Pearson Education Limited.

Creswell, John W., Vicki L., \& Plano Clark. (2007). Designing and Conducting Mixed Methods Research. Thousand Oaks: SAGE Publications.

Estirahayu, D.P., Siti, R. H., \& Raden, R. H (2014). Pengaruh Rasio Likuiditas, Rasio Leverage, dan Rasio Aktivitas terhadap Kinerja Keuangan Perusahaan. Studi pada Perusahaan Food and Beverage yang Listing di Bursa Efek Indonesia Tahun 20102012). Jurnal Administrasi Bisnis (JAB), 8(1).

Gitman, Lawrence J., \& Prihadi, Toto. (2008). Quick Detection of Financial Condition. 7 Financial Ratio Analysis. Jakarta: PPM.

Kasmir. (2013). Analisis Laporan Keuangan. Cetakan Keenam. Jakarta: Raja Grafindo Persada.

Kasmir. (2015). Analisis Laporan Keuangan. Jakarta: PT Raja Grafindo Persada.

Kenton, Will. \& Adam Hayes. (2019). Debt-To-Equity Ratio-D/E. Investopedia. (Retrieved from: https://www.investopedia.com/terms/d/debtequityratio.asp/5-5-2020).

Kenton, Will. (2019). Activity Ratios Definitions. Investopedia. (Retrieved from:https://www.investopedia.com/terms/a/activityratio.asp/5-5-2020).

Lewis, at al. (2004). Handbook of Emotion. Second Edition. New York: Springer Verlag.

Munawir. (2007). Analisa Laporan Keuangan. Yogyakarta: Liberty.

Sudana, I Made. (2011). Manajemen Keuangan Perusahaan. Teori dan Praktik. Jakarta: Erlangga. 